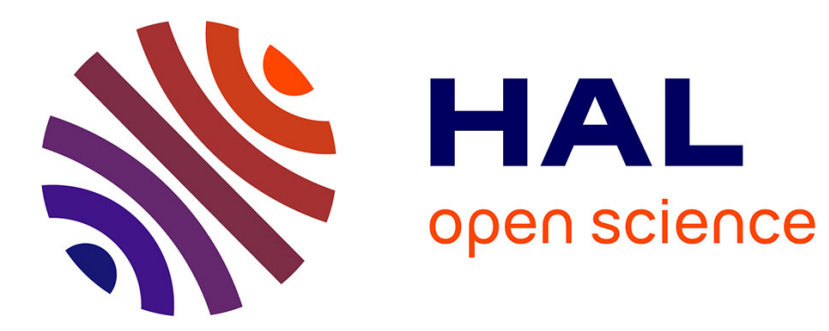

\title{
Take a deep breath and check your heart
}

François Alhenc-Gelas

\section{To cite this version:}

François Alhenc-Gelas. Take a deep breath and check your heart. Journal of Diabetes and its Complications, 2016, 10.1016/j.jdiacomp.2016.03.002 . hal-01284546

\section{HAL Id: hal-01284546 https: / hal.sorbonne-universite.fr/hal-01284546}

Submitted on 7 Mar 2016

HAL is a multi-disciplinary open access archive for the deposit and dissemination of scientific research documents, whether they are published or not. The documents may come from teaching and research institutions in France or abroad, or from public or private research centers.
L'archive ouverte pluridisciplinaire HAL, est destinée au dépôt et à la diffusion de documents scientifiques de niveau recherche, publiés ou non, émanant des établissements d'enseignement et de recherche français ou étrangers, des laboratoires publics ou privés. 


\section{Take a deep breath and check your heart}

The physician is often faced with diagnosing causes of dyspnea in its clinical practice. Patients may spontaneously complain from shortness of breath but otherwise, and often, the symptom has to be recognized and extracted from patient's history through questioning (Banzett R.B., \& Schwartzstein, 2015). In most cases, dyspnea occurs because normal breathing frequency and amplitude does not allow delivering appropriate oxygen supply to tissues and maintaining low blood carbon dioxide or hydrogen ions $(\mathrm{pH})$ concentration, at rest and/or at exercise. This occurs especially in the brain, triggering chemoreceptor stimulation and causing feeling of discomfort. Besides several different conditions pertaining to respiratory, haematological or neurological disorders, coronary insufficiency and heart failure are leading causes of dyspnea. Dyspnea is then due to non-adaptation of cardiac output to peripheral organ metabolism and, in congestive heart failure, to pulmonary hemodynamic alterations.

Cardiac causes of dyspnea are frequent and dyspnea is a bad prognosis indicator. In a large cohort study, subjects presenting with dyspnea and otherwise asymptomatic had over a few years an incidence of death of cardiac causes, including sudden death, several fold higher than subjects that were not suffering from the symptom (Abidov et al., 2005). Diabetes (presumably mainly type 2) was more frequent in subjects reporting dyspnea than in nondyspneic subjects (Abidov et al., 2005). In type 1 diabetes, cardiac involvement is frequent and may occur early (Boudina \& Abel, 2007; Wai et al , 2014). Cardiac disease remains a main cause of death (Harjutsalo, Forsblom \& Groop, 2011). Thus recognizing cardiac dysfunction at its early stage in patients with type 1 diabetes is a clinical need. This should lead to thoroughly checking glycemic control and may trigger use of treatments aimed at preserving ventricular function through lowering of peripheral resistance and/or desobstruction of coronary arteries.

Can dyspnea be considered as an early marker of cardiac dysfunction in type 1 diabetes? The study by Jensen et al in the present issue (Jensen et al., 2016) attempts at addressing the question in a well phenotyped population. Cardiac function was evaluated by speckle-tracking echocardiography. This technique is an improvement of two-dimensional cardiac echography and is considered to accurately allow analysis of global and regional myocardial deformation in all spatial directions. It provides information on left ventricular longitudinal, rotational and torsional dynamics, in a simpler way than magnetic resonance imaging (Mondillo et al., 2011). The study shows that dyspnea is indeed associated with alterations in ventricular dynamics by this technique in patients with no previously known heart disease and normal ventricular ejection fraction. These alterations are consistent with systolic and diastolic dysfunction. The data document the potential interest of speckle tracking echography over conventional echography for diagnosing incipient diabetic cardiac disease, although confirmation of ventricular dysfunction by hemodynamic study or magnetic resonance imaging was not sought. Patients presenting with these echographic abnormalities could however be further evaluated by monitoring of blood pressure and tests aimed at detecting subclinical coronary atherosclerosis.

Interest of the study relies on both its epidemiological and clinical aspects but there is limitation in the practical usefulness of these observations. Firstly, association is mainly due to patients with the most severe stages of dyspnea (severely limiting physical activity, New York Heart Association classification class III-IV) and is weak or absent in those with the more benign and common forms of the symptom. Secondly, association is not causality, which can be difficult documenting here. Accordingly, non-cardiac causes of dyspnea should not be overlooked in otherwise asymptomatic diabetic patients (Hsia \& Raskin, 2008; Thomas et al., 2003). In any case, the Jensen et al study addresses, with a new technology, the difficult issue of diagnosing incipient cardiac dysfunction in diabetic patients. Together with other, 
related studies performed in patients with type 2 diabetes and in animals (Ernande et al., 2010; $\mathrm{Li}$ et al 2014) it should provide impetus for further evaluation of speckle-tracking cardiac echography in diabetic patients.

\section{References}

Abidov, A., Rozanski, A., Hachamovitch, R., Hayes, S. W., Aboul-Enein, F., Cohen, I., \& Berman, D. S. (2005). Prognostic significance of dyspnea in patients referred for cardiac stress testing. New England Journal of Medicine,353(18), 1889-1898.

Banzett R.B., \& Schwartzstein R.M. (2015). Dyspnea: Don't Just Look, Ask! Am J Respir Crit Care Med, 192(12), 1404-6.

Boudina, S., \& Abel, E. D. (2007). Diabetic cardiomyopathy revisited. Circulation, 115(25), 3213-3223.

Ernande, L., Rietzschel, E. R., Bergerot, C., De Buyzere, M. L., Schnell, F., Groisne, L. Ovize M., Croisille P., Moulin P., Gillebert T., \& Derumeaux, G. (2010). Impaired myocardial radial function in asymptomatic patients with type 2 diabetes mellitus: a speckle-tracking imaging study. Journal of the American Society of Echocardiography, 23(12), 12661272.

Harjutsalo, V., Forsblom, C., \& Groop, P. H. (2011). Time trends in mortality in patients with type 1 diabetes: nationwide population based cohort study. Bmj,343, d5364.

Hsia, C. C., \& Raskin, P. (2008). Lung involvement in diabetes Does it matter? Diabetes Care, 31(4), 828-829.

Jensen, M.T., Risum, N., Rossing, P., Jensen J.S. (2016). Self-Reported dyspnea is associated with impaired global longitudinal strain in ambulatory type 1 diabetes patients with normal ejection fraction and without known heart disease. J Diabetes Complications.

Li, R. J., Yang, J., Yang, Y., Ma, N., Jiang, B., Sun, Q. W., \& Li, Y. J. (2014). Speckle tracking echocardiography in the diagnosis of early left ventricular systolic dysfunction in type II diabetic mice. BMC cardiovascular disorders, $14,141$.

Mondillo, S., Galderisi, M., Mele, D., Cameli, M., Lomoriello, V. S., Zacà, V., ... \& D’Errico, A. (2011). Speckle-tracking echocardiography a new technique for assessing myocardial function. Journal of Ultrasound in Medicine, 30(1), 71-83.

Thomas, M. C., MacIsaac, R. J., Tsalamandris, C., Power, D., \& Jerums, G. (2003). Unrecognized anemia in patients with diabetes A cross-sectional survey. Diabetes care, 26(4), 1164-1169.

Wai, B, Patel, SK, Ord, M, MacIsaac, RJ, Jerums, G, Srivastava, PM, \& Burrell, LM.(2014). Prevalence, predictors and evolution of echocardiographically defined cardiac abnormalities in adults with type 1 diabetes: an observational cohort study. J Diabetes Complications, 28(1), 22-8.

Francois Alhenc-Gelas

Institut national de la Sante et de la recherche Medicale; Paris- Descartes University; Pierre et Marie Curie University ; Centre de Recherche des Cordeliers (INSERM U1138), 15 rue de l'Ecole de Medecine, 75006 Paris, France. francois.alhenc-gelas@inserm.fr 